Tyndale Bulletin 68.2 (2017) 223-239

\title{
THE MEANING OF XЕIP'ОГРАФON IN COLOSSIANS 2:14 REVISITED
}

\author{
Kyu Seop Kim \\ (kyuseopkim77@gmail.com)
}

\begin{abstract}
Summary

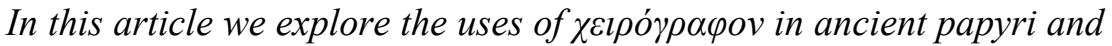

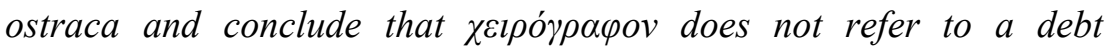
certificate, contrary to scholars' consensus (except for Peter Arzt-

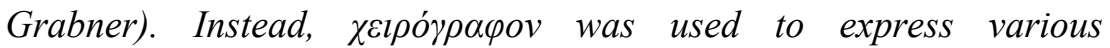
handwritten declarations including receipts, loans, contracts, and

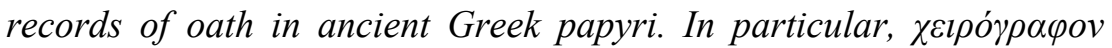

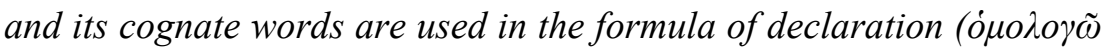

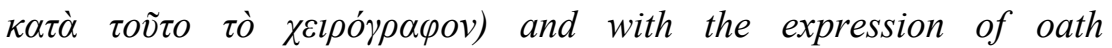

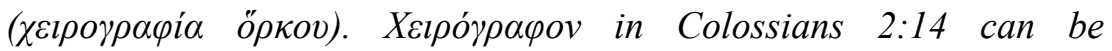
interpreted in this context. Declaration or oath on the observance of religious regulations was significant in ancient paganism and Judaism.

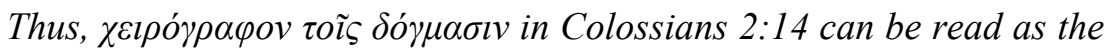
handwritten document which contains the declaration or oath with regard to the observance of religious regulations.
\end{abstract}

\section{Introduction}

There has been a long history of scholarly disputes surrounding the

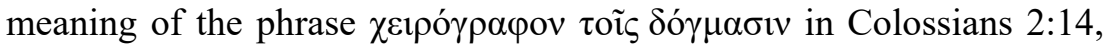
but the solutions suggested by interpreters remain unsatisfactory. In general, most scholars agree that $\chi \varepsilon 1 \rho o ́ \gamma \rho \alpha \varphi o v$ in Colossians 2:14 refers to a certificate of indebtedness. In his monumental work Licht vom Osten $^{1}$ Adolf Deißmann argues that $\chi \varepsilon ı \rho o ́ \gamma \rho \alpha \varphi o v$ in Colossians 2:14

1 Adolf Deißmann, Licht vom Osten: Das Neue Testament und die neuentdeckten Texte der hellenistisch-römischen Welt (Tübingen: Mohr Siebeck, 1908), 240-41. 
was meant as 'Schuldhandschrift' (i.e. an i.o.u.), according to his papyrological evidence.

Deißmann's interpretation has been supported by the majority of scholars, ${ }^{2}$ who maintain that the term in Colossians 2:14 reflects a Jewish idea that regards God as a heavenly creditor and humanity as a debtor. Some scholars argue that $\chi \varepsilon i \rho o ́ \gamma \rho \alpha \varphi o v$ in Colossians 2:14 symbolises some threats to the soteriological certainty of the Colossian saints. Eduard Schweizer states that $\chi \varepsilon i \rho o ́ \gamma \rho \alpha \rho o v$ refers to a private document which was not certified by a notary and that $\chi \varepsilon \iota \rho o ́ \gamma \rho \alpha \rho \circ v$ in Colossians 2:14 was meant as a certificate of indebtedness which can jeopardise the certainty of salvation of the Colossian believers. ${ }^{3}$ In the same vein, Joram Luttenberger also associates $\chi \varepsilon i \rho o ́ \gamma \rho \alpha \varphi o v$ with

2 E.g. Rudolf Hoppe, Der Triumph des Kreuzes: Studien zum Verhältnis des Kolosserbriefes zur paulinischen Kreuzestheologie (Stuttgart: Katholisches Bibelwerk, 1994), 254-55; Michael Dübbers, Christologie und Existenz im Kolosserbrief: Exegetische und semantische Untersuchungen zur Intention des Kolosserbriefes (WUNT II/191; Tübingen: Mohr Siebeck, 2005), 257; Nikolaus Walter, 'Die Handschrift in Satzungen Kol 2,14', ZNW 70 (1979), 115-18; Joram Luttenberger, 'Der gekreuzigte Schuldschein: Ein Aspekt der Deutung des Todes Jesu im Kolosserbrief', NTS 51 (2005), 92-93; C. Masson, L'Epître de Saint Paul aux Colossiens (Neuchâtel: Delachaux, 1950), 127-29; T. J. Lang, 'Disbursing the Account of God: Fiscal Terminology and the Economy of God in Colossians 1,24-2514', ZNW 107 (2016), 136; Roy Yates, 'Colossians 2:14: Metaphor of Forgiveness', Biblica 71 (1990), 24859; Roy Yates, 'Colossians 2:15: Christ Triumphant', NTS 37 (1991), 583; J. D. G. Dunn, Colossians and Philemon (NIGTC; Grand Rapids: Eerdmans, 1996), 164; Peter T. O'Brien, Colossians, Philemon (WBC; Waco: Word, 1982), 124; Douglas, J. Moo, The Letters to the Colossians and to Philemon (PNTC; Grand Rapids, 2008), 209; E. Percy, Die Probleme der Kolosser- und Epheserbriefe (Lund: Gleerup, 1946), 89; Ben Witherington III, The Letters to Philemon, the Colossians, and the Ephesians: A SocioRhetorical Commentary on the Captivity Epistles (Grand Rapids: Eerdmans, 2007), 158; Stephen E. Fowl, The Story of Christ in the Ethics of Paul: An Analysis of the Function of the Hymnic Material in the Pauline Corpus (JSNTSup 36; Sheffield: Sheffield Academic Press, 1990), 142-43; Margaret Y. MacDonald, Colossians and Ephesians (Sacra Pagina 17; Collegeville: Liturgical Press, 2000), 102; T. K. Abbott, The Epistles to the Ephesians and to the Colossians (Edinburgh: T\&T Clark, 1897), 255; Andreas Lindemann, Der Kolosserbrief (Zürich: Theologischer Verlag, 1983), 44.

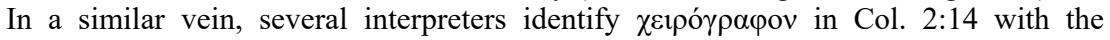
Mosaic Law in respect of the condemnatory force or as the bill of indictment. See Heinrich J. Holzmann, Kritik der Epheser- und Kolosserbrief auf Grund einer Ihres Verwandtschaftsverhältnisses (Leipzig: Von Wilhelm Engelmann, 1872), 207; B. J. Oropeza, Jews, Gentiles, and the Opponents of Paul: Apostasy in the New Testament Communities, vol. 2 (Eugene: Cascade, 2012), 249; Michael F. Bird, Colossians and Philemon (NCCS 12; Eugene: Cascade, 2009), 80; Murray J. Harris, Colossians and Philemon (Grand Rapids: Eerdmans, 1991), 107; Markus Barth and Helmut Blanke, Colossians: A New Translation with Introduction and Commentary (trans. Astrid B. Beck; New York: Anchor, 1994), 371.

3 Eduard Schweizer, The Letter to the Colossians: A Commentary (trans. Andrew Chester; Minneapolis: Fortress, 1982), 150-51. 
accusation and condemnation, and argues that $\chi \varepsilon 1 \rho o ́ \gamma \rho \alpha \varphi \rho v$ in Colossians 2:14 refers to a certificate of debts (Schuldenbelege) ${ }^{4} \mathrm{He}$ discovers his evidence in BGU 664 and BGU 472,5 and states that $\delta$ ó $\gamma \mu \alpha$ in Colossians 2:14 formulates the obligation of the debtor towards the creditor. ${ }^{6}$ Accordingly, $\chi \varepsilon$ éó $\gamma \rho \alpha \varphi$ ov in Colossians 2:14 is linked with all transgressions of human beings. ${ }^{7}$

Whereas Nikolaus Walter maintains that $\chi \varepsilon i \rho o ́ \gamma \rho \alpha \varphi o v$ in Colossians 2:14 undoubtedly refers to the certificate of indebtedness, Walter suggests that God should not be considered as a heavenly creditor who calculates human guilt in Colossians 2:14. In his perspective, $\chi \varepsilon i \rho o ́ \gamma \rho \alpha \varphi \circ v$ is also associated with the confession of indebtedness as sinners in the given context, ${ }^{8}$ and $\chi \varepsilon \varphi \rho o ́ \gamma \rho \alpha \varphi \rho v$ does not merely symbolise the accusation from God the heavenly creditor, but also the anxiety for their sins (Sündenangst) by the Colossian believers. ${ }^{9}$ Yet, while many interpreters agree with the view that $\chi \varepsilon 1 \rho$ ó $\rho \rho \alpha \rho v$ in Colossians 2:14 was meant as a certificate of indebtedness, this view does not sufficiently explain the reason why the certificate of indebtedness is modified by $\tau$ oĩ $\delta o ́ \gamma \mu \alpha \sigma v v$ in Colossians 2:14.

Second, on the basis of the first option (i.e. a debt certificate), some

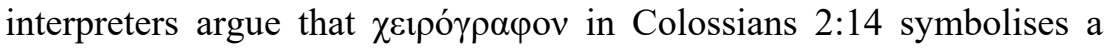
celestial scroll that records human sins. ${ }^{10}$ For example, Eduard Lohse appeals to Apocalypse of Zephaniah 3:6-9 and Apocalypse of Paul 17, where the handwritten document is associated with a heavenly book,

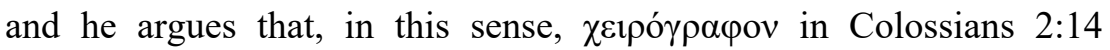

4 Luttenberger, 'Der gekreuzigte Schuldschein', 88.

5 Luttenberger, 'Der gekreuzigte Schuldschein', 84-85.

6 Luttenberger, 'Der gekreuzigte Schuldschein', 88.

7 Luttenberger, 'Der gekreuzigte Schuldschein', 87. Luttenberger insists that baptism in Col. 2:14 is considered as the place where sins are remitted. He reaches a conclusion that Christ crucified is Schuldurkunde des Lebens. Luttenberger, 'Der gekreuzigte Schuldschein', 95.

8 Walter, 'Die Handschrift in Satzungen Kol 2,14', 117.

9 Walter, 'Die Handschrift in Satzungen Kol 2,14', 118.

10 E.g. Schweizer, Kolosser, 105; Olivia A. Blanchette, 'Does the Cheirographon of Col. 2:14 Represent Christ Himself?' CBQ 23 (1961), 306-12; Thomas J. Sappington, Revelation and Redemption at Colossae (JSNTSup 53; Sheffield: Sheffield Academic Press, 1991), 100-108; Walter T. Wilson, The Hope of Glory: Education and Exhortation in the Epistle to the Colossians (NovTSup 88; Leiden: Brill, 1997), 30; Robert L. Cavin, New Existence and Righteous Living: Colossians and 1 Peter in Conversation with 4QInstruction and the Hodayot (BZNW 197; Berlin: Walter de Gruyter, 2013), 140-42. See Sappington, Revelation and Redemption, 100-108,216217; Ian Smith. Cf. H. Weiss, 'The Law in the Epistle to the Colossians', $C B Q 34$ (1972), 294-314. 
symbolises accusation or condemnation. ${ }^{11}$ Yet, the term $\chi \varepsilon 1 \rho o ́ \gamma \rho \alpha \varphi \circ v$ originally refers to a handwritten declaration, so it seems that the usage of chirographum in this tradition could be figuratively used to stress the sense of the heavenly book as an official declaration. Moreover, it is unclear that $\chi \varepsilon ı \rho o ́ \gamma \rho \alpha \varphi o v$ in Colossians 2:14 can refer to a heavenly book without any explicit explanation in the given context.

Thus, NT scholars generally agree that $\chi \varepsilon i \rho o ́ \gamma \rho \alpha \varphi o v$ refers to a debt certificate. We find an exception in Peter Arzt-Grabner's commentary on Philemon, where he briefly observes that $\chi \varepsilon i \rho o ́ \gamma \rho \alpha \varphi o v$ was not merely a debt certificate, but the most important document type in the private law in the second or third century AD. ${ }^{12}$ Yet, we will explore that $\chi \varepsilon 1 \rho o ́ \gamma \rho \alpha \varphi \circ$ vas not simply used for a private purpose, but in an

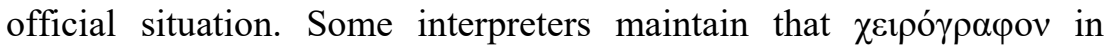
Colossians 2:14 is related to accusation or condemnation, and that

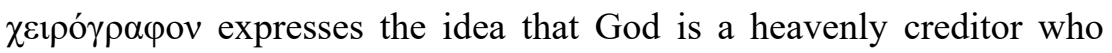
calculates human transgressions. However, this study will offer an alternative interpretation of Colossians 2:14. For this purpose, we will examine the uses of $\chi \varepsilon i \rho o ́ \gamma \rho \alpha \varphi o v$ and its cognate words (i.e. $\chi \varepsilon i \rho о \gamma \rho \alpha \varphi i ́ \alpha$ and $\chi \varepsilon i \rho о \gamma \rho \alpha \varphi \varepsilon i v)$ in ancient papyri and ostraca written in the second century $\mathrm{BC}$ to the third century AD. ${ }^{13}$

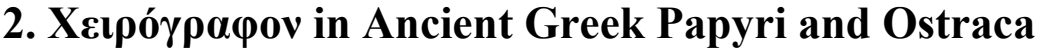

The majority of NT scholars concur that $\chi \varepsilon 1 \rho o ́ \gamma \rho \alpha \varphi \rho v$ in Colossians 2:14 refers to a certificate of indebtedness, as discussed above. Yet, it should be recognised that the term $\chi \varepsilon i \rho o ́ \gamma \rho \alpha \varphi o v$ does not refer to a debt certificate, contrary to Deißmann's argument, but can be defined as a main certificate type of ancient private law. ${ }^{14} \mathrm{We}$ will explore this point in this section. For instance, $\chi \varepsilon \iota \rho o ́ \gamma \rho \alpha \varphi \circ$ v was used in various documents such as a lease contract (P.Fouad 40, AD 35), house sale contract (P.Louvre 1:10, AD 75-99), farm sale contract (P.Mich. 5:272,

\footnotetext{
11 Lohse, Kolosser, 110-11.

12 Peter Arzt-Grabner, Philemon (Papyrologische Kommentare zum Neuen Testament Band 1; Göttingen: Vandenhoeck \& Ruprecht, 2003), 240-41.

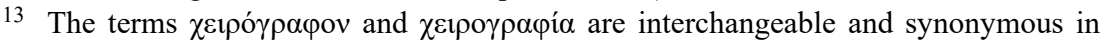
many cases. Cf. P.Oxy. 4.719; P.Cair.goodsp. 21,22,24,33,44,47,72,74, etc.

14 Otto Gradenwitz, Einführung in die Papyruskunde (Leipzig: Von S. Hirzel, 1900), 38. Cf. Winfried Trusen, 'Chirographum und Teilurkunde im Mittelalter', Archivalische Zeitschrift 75 (1979), 233-49.
} 


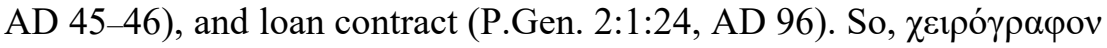
was a general term referring to an official handwritten declaration between two contractors. ${ }^{15}$

For example, it is stated in a papyrus concerning a house sale contract (P.Oxy. 3:983) that some property was sold according to

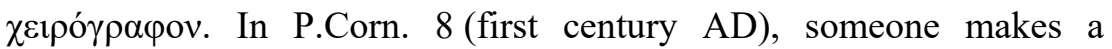

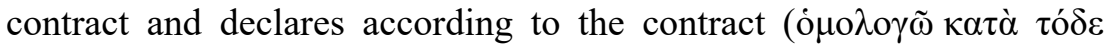

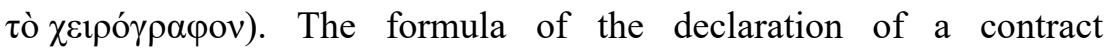

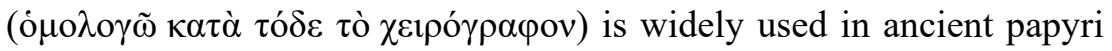
(e.g. P.Amst. 1:44; BGU 1:50; BGU 1:272; P.Fay. 34; P.Bad. 2:25; P.Princ. 3:149; P.Stras. 5:370; Stud.Pal. 20:3, etc.). In this case, the

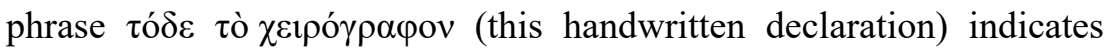
that $\chi \varepsilon i \rho o ́ \gamma \rho \alpha \varphi$ v was meant as the document that contains a declaration made by the contractors.

The author of P.Amh. 2:67 (AD 231-237) recorded a judicial proceeding, and states the following:

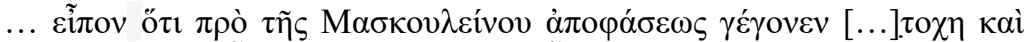

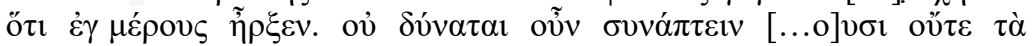

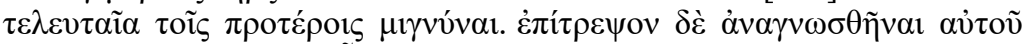

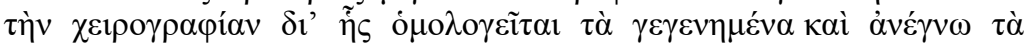

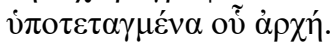

... I said that before the verdict of Markouleinos, he became [...] and that he ruled on his behalf. Therefore, he cannot join to [...] nor be united with the seniors at last. Permit to read the handwritten declaration through which he acknowledges what was decided and he has read what is subjected from the beginning.

In this papyrus, the council of Alexandria and Aurelius Serenos Dioskopos hand down a verdict, and $\chi \varepsilon \iota \rho o \gamma \rho \alpha \varphi$ í refers to the handwritten declaration of this verdict ( $\alpha$ ró $\varphi \alpha \sigma \iota)$ ). In this case, what

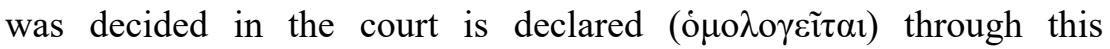

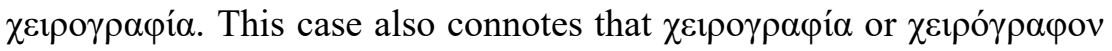
is related to the concept of official declaration.

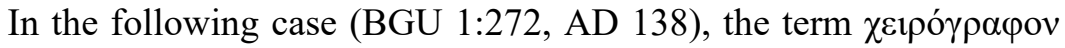
is used with the formula of the declaration of a contract ( $\dot{0} \mu \mathrm{o} \lambda \mathrm{o} \gamma \tilde{\omega} \kappa \alpha \tau \grave{\alpha}$

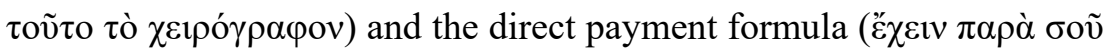

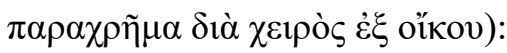

15 E.g. contract (BGU 1.50, P.Oslo. 3.161, O.Claud. 1.156, P.Corn. 8); hiring document (P.Mich. 11.603); bond (P.Oxy. 75.5052, O.Claud 1.156, P.Col. 10.287, P.Heid. Gr. 3.239), receipt (BGU 1.104, BGU 1.172, BGU 2.440, BGU 2.441, BGU 2.443, P.Col. 7.145, P.Col. 7.158, P.Aberd. 49), bank document (P.Oxy. 75.5052), etc. 


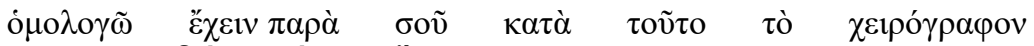

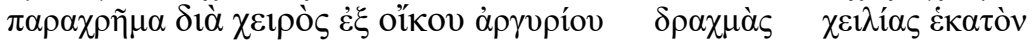
Eǐkoбl ...

I declare that I received from you according to this handwritten

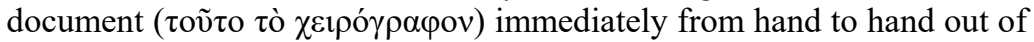
the house, valued at 1120 drachma ...

In this case, $\chi \varepsilon i \rho o ́ \gamma \rho \alpha \varphi o v$ refers to a contract document for a house sale, and is used in the private contract situation with the direct payment formula which indicates a private contract between two contractors. ${ }^{16}$ The direct payment formula was employed in various contract papyri. For instance, in P.Mich. 5:272, Herakles, son of Panouris, sells a part of his palm garden as follows:

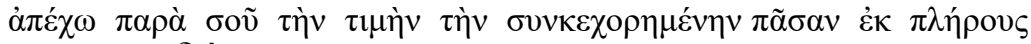

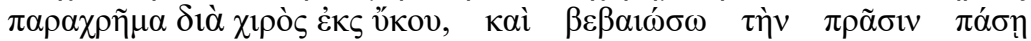

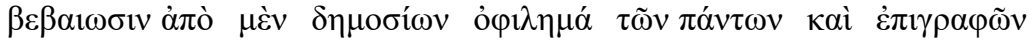
$\pi \alpha \sigma \tilde{\nu}$.

I have received from you the entire price agreed upon, fully immediately by hand out of the house, and I guarantee this transaction with every guarantee, from all public debts and all registers.

The direct payment formula is utilised in many cases of a private contract made immediately between two contractors: the verb of

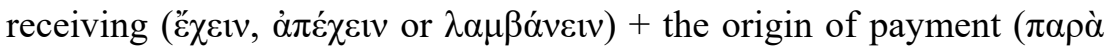

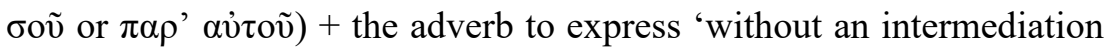
of the third party' $(\pi \alpha \rho \alpha \chi \rho \tilde{\eta} \mu \alpha)+$ a direct means of payment

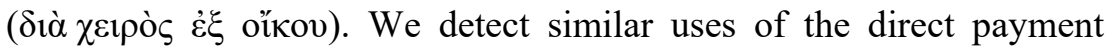
formula in many ancient contract papyri. ${ }^{17}$ In his Life of Caius Martius Coriolanus 2, Plutarch also mentions this formula:

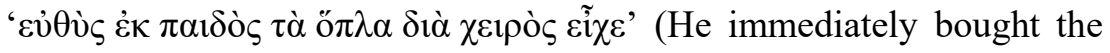
arms from the servant by direct payment). This formula was also used in ancient marriage contracts about dowries (e.g. BGU 4:1050; BGU 4:1103; BGU 4:1104, etc.). By contrast, if there is a bank involved, the

16 For similar cases, see BGU 3.800; P.Mich. 9.573; P.Bad. 2.25; P.Diog.27; P.Diog. 31dupl; P.Nyu. 2.23; P.Princ. 3.149; Stud.Pal.20.3.

17 E.g. P.Lond. 2.143; C.Pap.Gr. 1.7; P.Ryl. 2.177; P.Mich 3.188; P.Mich 4.550; BGU 4.1057; BGU 4.1147; BGU 1.183; BGU 4.1050; P.Fam.Tebt. 10; BGU 4.1145; BGU 4.1130; BGU 4.1126; BGU 4.1122; BGU 4.1150; BGU 4.1154; BGU 4.1155; BGU 7.1664; BGU 7.1650; BGU 4.1175; BGU 4.1174; BGU 11.2111; BGU 11.2121; BGU 13.2330; BGU 15.2476; BGU 15.2477; BGU 15.2478; CPR 1.2; CPR 1.3; CPR 1.28; CPR 1.64; CPR 1.88; CPR 1.90; CPR 1.203; P.Amh, 2.111; P.Atheion 21; P.Fay.91; P.Louvre. 1.9; P.Hamb.3.218; P.Fam.Tebt. 23; P.Flor. 1.51; P.Fouad 40; P.Hamb. 3.218; P.Kron. 48; P.Louvre 1.10, etc. 


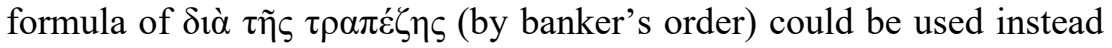

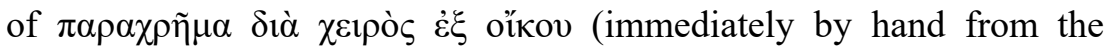
house). ${ }^{18}$ So, we find that the term $\chi \varepsilon i \rho o ́ \gamma \rho \alpha \varphi o v$ was used with the

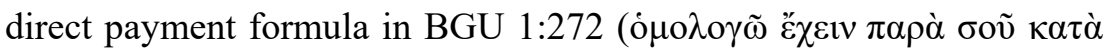

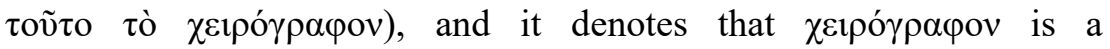
stereotyped word referring to the document which contains a declaration made by two contractors.

The term $\chi \varepsilon i \rho o ́ \gamma \rho \alpha \varphi$ v was used in the document of a slave sale (P.Oxy. 60:4058, AD 158-159):

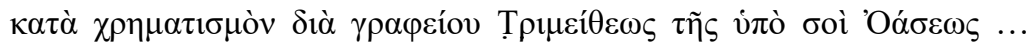

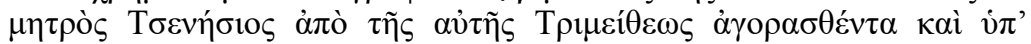

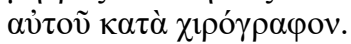

According to the transaction through the record officer of Trimeitheos of Oasis near to you ... sold from Trimeitheos her son and by him

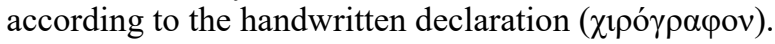

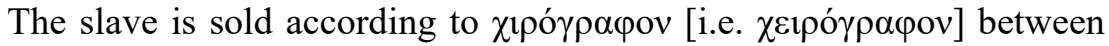
the contractors in this papyrus, the transaction is warranted by the public grapheion (record office), and the sale of the slave is declared by

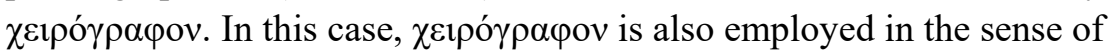
the declaration of the contract.

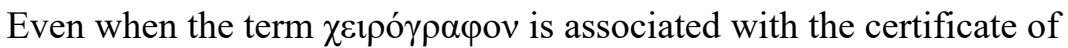
indebtedness, it was not directly meant as the certificate of indebtedness or the bond: it simply refers to the document or the certificate with regard to a handwritten declaration. In P.Mich. 11:614 (AD 256), Aurelius Papontheus's sons appeal to Aurelius Sarapion, strategos of the Oxyrhynchite nome, because Aurelius Horos did not repay his debt for thirty-four years. In this papyrus, the term $\chi \varepsilon 1 \rho o ́ \gamma \rho \alpha \varphi \circ v$ refers to the original loan contract with the debtor:

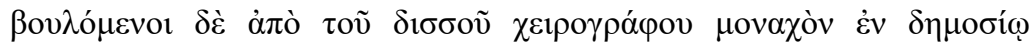

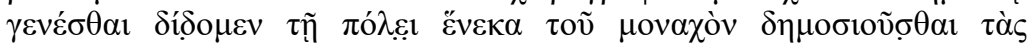

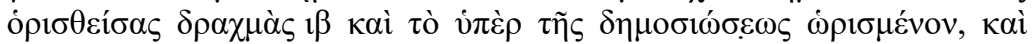

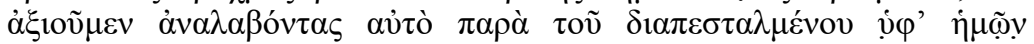

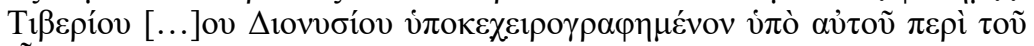

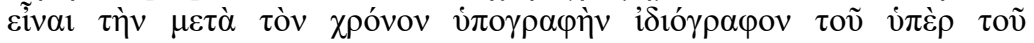

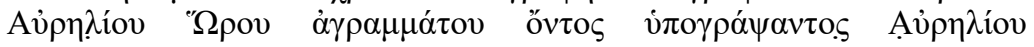

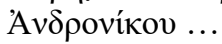

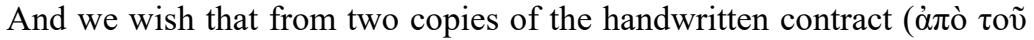
$\delta ı \sigma \sigma o \tilde{~} \chi \varepsilon \iota \rho о \gamma \rho \alpha ́(\varphi o v)$, a single copy will be made public, and we submit

18 E.g. P.Oxy. 55.3798; BGU 2.445; BGU 3.702; BGU 8.1156, etc. 
it to the city, because the single copy will be made public, the determined 12 drachmai and the fee for the publication, and we desire that you will take it from our representative, Tiberius ... Dionysios,

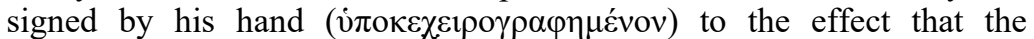
subscription after the date is of the illiterate Aurelius Horos' signatory Aurelius Andronikos.

Ostensibly, it is likely that $\chi \varepsilon \varphi \rho o ́ \gamma \rho \alpha \varphi o v$ refers to a debt certificate, but we discover the same formula in SB 24:16265 (approximately AD 259) as follows:

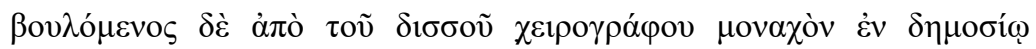

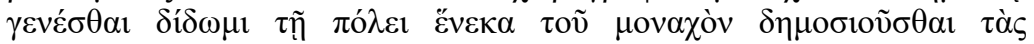

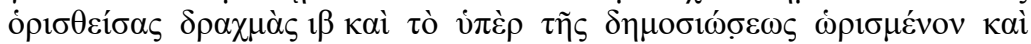

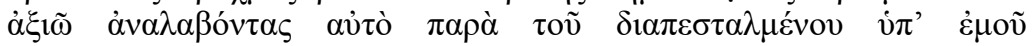

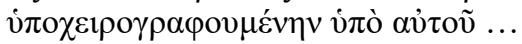

And I wish that from two copies of the handwritten contract ( $\dot{\alpha} \pi$ ò $\tau$ ov $\delta ı \sigma \sigma o \tilde{~} \chi \varepsilon i \rho о \gamma \rho \alpha ́(\varphi o v)$, a single copy will be made public, and I submit it to the city, because the single copy will be made public, the determined 12 drachmai and the fee for the publication, and I desire that you will take it from my representative signed by his hand ...

In this case, Aurelia Isadora purchased some wine, and paid for it, but the wine was not delivered. So, she petitioned to the strategos with the original sale contract ( $\chi \varepsilon i \rho o ́ \gamma \rho \alpha \varphi o v)$ in this papyrus. In this case, $\chi \varepsilon i \rho o ́ \gamma \rho \alpha \varphi \circ v$ is not related to the certificate of indebtedness, but refers to the handwritten sale contract in SB 24:16265. Likewise, it is apparent that $\chi \varepsilon i \rho o ́ \gamma \rho \alpha \varphi o v$ in the same formula was not also meant as a debt certificate in P.Mich. 11:614, but as the declaration of the contract. Thus, $\chi \varepsilon \iota \rho o ́ \gamma \rho \alpha \varphi o v$ does not refer to a debt certificate itself, but to a handwritten declaration, even when it is used in respect of a loan or a bond.

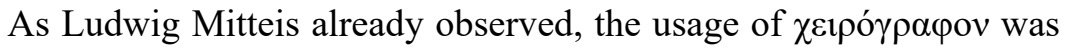
not limited to a private contract, but also to public situations. ${ }^{19}$ Nonetheless, most NT scholars maintain that $\chi \varepsilon \imath \rho o ́ \gamma \rho \alpha \varphi o v$ was used only in a private situation. For instance, Ernst Lohmeyer associates

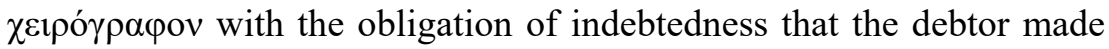
by his own hand without the involvement of a notary. ${ }^{20}$ Luttenberger

19 Ludwig Mitteis, Reichsrecht und Volksrecht in den östlichen Provinzen des römischen Kaiserreichs, mit Beiträgen zur kentniss des griechischen Rechts und der spätrömischen Rechtsentwicklung (Leipzig: Teubner, 1891), 494.

20 Lohmeyer, Kolosser, 100. 
also argues that $\chi \varepsilon \iota \rho \gamma^{\prime} \rho \alpha \varphi v$ refers to a debt certificate in a more private form. ${ }^{21}$

While $\chi \varepsilon i \rho o ́ \gamma \rho \alpha \varphi$ ov could be used in private situations, we have some evidence that $\chi \varepsilon i \rho o ́ \gamma \rho \alpha \varphi \circ v$ could also be employed with regard to a public situation. The term $\chi \varepsilon i \rho o ́ \gamma \rho \alpha \varphi o v$ was also associated with the receipt of grain and tax:

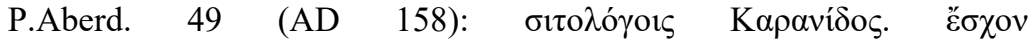

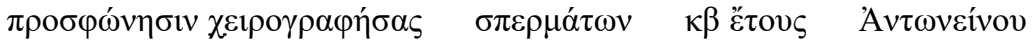

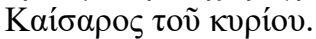

To the collectors of grains in Karanis. I received the hand-written

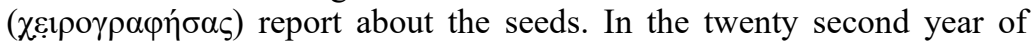
Antonius Caesar the Lord.

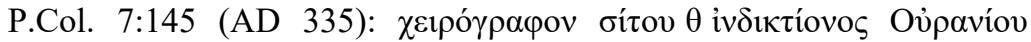
Паv́ภov.

The receipt ( $\chi \varepsilon 1 \rho o ́ \gamma \rho \alpha \varphi o v)$ of grains. The 8th indiction of Uranios Paulus.

In the first case (P.Aberd. 49), $\pi \rho \circ \sigma \varphi \omega ́ v \eta \sigma ı ~ \chi \varepsilon ı \rho о \gamma \rho \alpha \varphi \eta ́ \sigma \alpha \varsigma$ refers to a handwritten report or a public declaration that grains were received. In

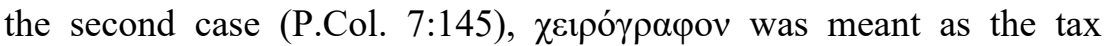
receipt about grains. In both cases, $\chi \varepsilon 1 \rho o ́ \gamma \rho \alpha \varphi o v$ and its cognate word ( $є є \iota \rho \gamma \rho \alpha \varphi \eta ́ \sigma \alpha \varsigma)$ are not merely limited to a private contract. ${ }^{22}$

In an official correspondence (P.Oxy. 10:1252, AD 288-295), the

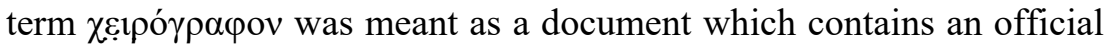
declaration, as follows.

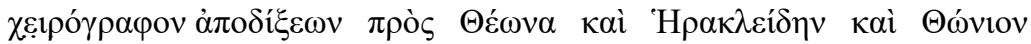

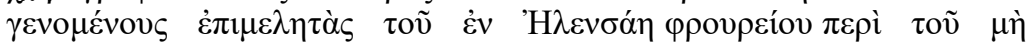

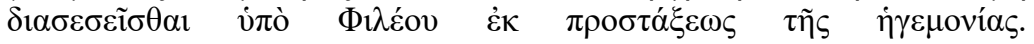

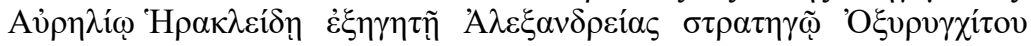

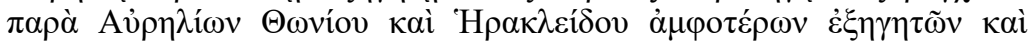

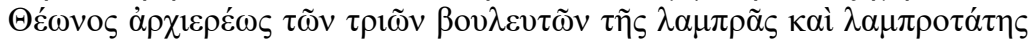

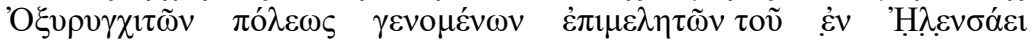

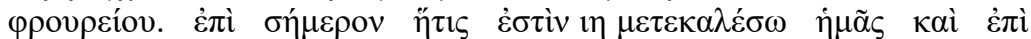

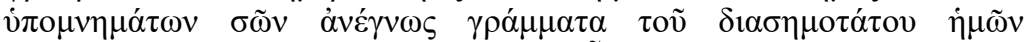

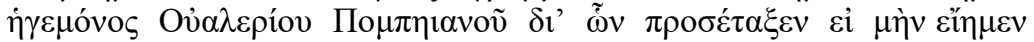

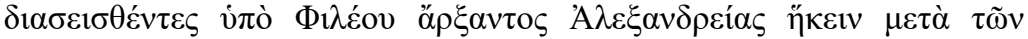

21 Luttenberger, 'Der gekreuzigte Schuldschein', 88.

22 The next example shows that $\chi \varepsilon i \rho o ́ \gamma \rho \alpha \varphi o v$ could refer to a document signed in

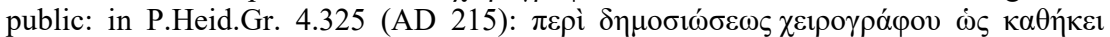

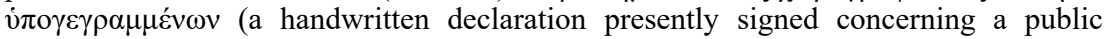
affair). 


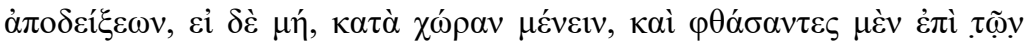

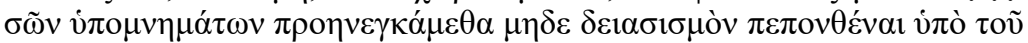

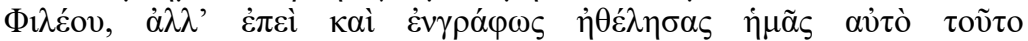

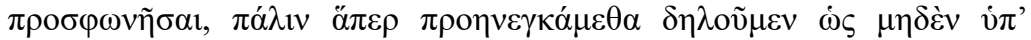

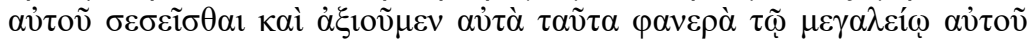
$\gamma \varepsilon v \varepsilon \dot{\sigma} \sigma \theta \alpha$.

The handwritten declaration ( $\chi \notin є$ เó $\gamma \rho \alpha \varphi$ ov) of proofs towards Theon and Herakleides and Thonios, former overseers of the fort in Helensaes concerning the fact that they experienced no extortion from Phileas according to the ordinance of the prefect. To Aurelios Herakleides, a translator of Alexandria, strategos of the Oxyrhynchite nome from Aurelios Thonios and Herakeides, both translators and Theon a chief interpreter ${ }^{23}$ of three senators of the brilliant and the most brilliant city of Oxyrhynchus, who took charge of guard in Helensaes. Until Today, it has been 18 years since you summoned us, and in your remembrance you have read the letter written by the most distinct prefect Oualerios Pompeianos, through which he commanded to come with the proofs as to whether we had suffered extortion from Phileas, a former magistrate of Alexandria, and if not, to stay at home, and we declared in your remembrance that we did not experience no extortion from Phileas, but you wanted us to write this statement, and we again make clear of the former declaration that nothing was extorted by him, and we desire these to be made known to his highness.

In this papyrus, Aurelios Thonios, Herakeides, and Theon declare that they were not extorted by Phileas, a former magistrate of Alexandria,

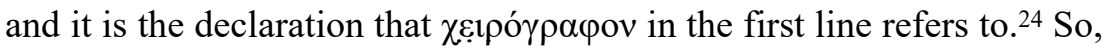

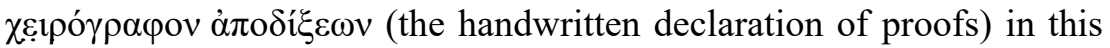
papyrus is an official declaration of proofs which demonstrates the guiltlessness of Phileas in his office as a magistrate.

On the other hand, the term $\chi \varepsilon i \rho o ́ \gamma \rho \alpha \varphi o v$ is employed in the sense of an official membership report for a guild (collegia). In P.Mich. 5:244 (AD 43), Kronious the son of Herodion is elected as a superintendent of tax collection for a guild, and he enumerates the names of the guild members in this papyrus. In the final line of P.Mich. 5:244, Kronious

23 In this case, $\dot{\alpha} \rho \chi 1 \varepsilon \rho \varepsilon \dot{\varepsilon} \omega \varsigma$ (high priest) seems to be a misspelling of $\dot{\alpha} \rho \chi \dot{\varepsilon} \rho \mu \eta v \varepsilon v ́ \varsigma$

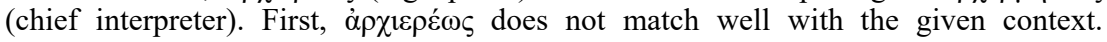

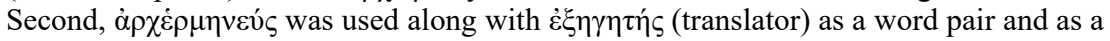
common official title. For example, an inscription discovered in Colossae (early

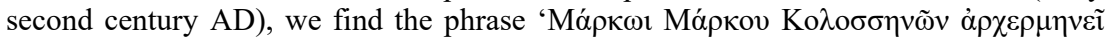

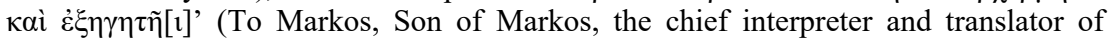
Colossae). For the text of this inscription, see A. H. Cadwallader, 'A New Inscription, a Correction, and a Confirmed Sighting from Colossae', Epigraphica Anatolica 40 (2007), 109-18.

24 For similar cases, see BGU 16.2571; BGU 16.2572. 


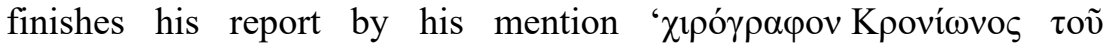

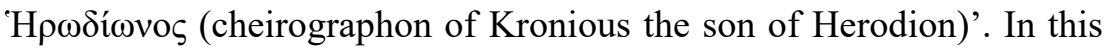

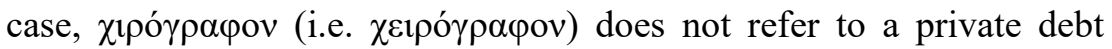
certificate or a private contract, but to an official declaration of guild membership for public tax.

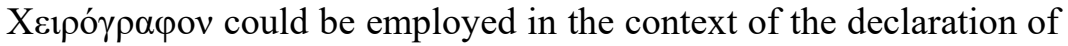
the official delegation. In P.Fay. 34 (AD 161), Heron is designated as a tax collector instead of the two former tax collectors at the village of Polydeucia, and $\chi \varepsilon i \rho o ́ \gamma \rho \alpha \varphi o v$ refers to the document of the delegation as a tax collector in this case:

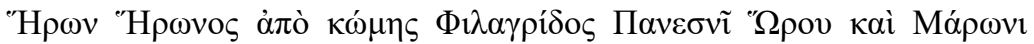

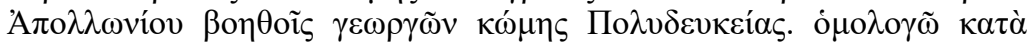

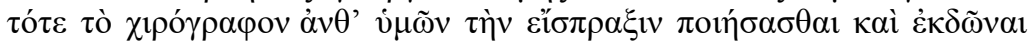

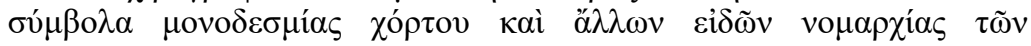

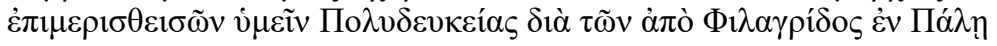

Heron, son of Heron from the village of Philagris, to Panes, son of Horos and Maron, son of Apolonios, assistants of farmers in the village of Polydeucia. According to this handwritten declaration, I acknowledge that I will practise the task of the tax collection and that the task for the

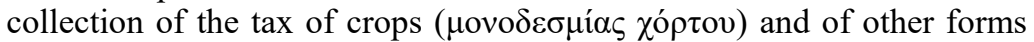
in Nomarkes which was formerly assigned to you will be substituted by the one from the village of Philagris in Pale.

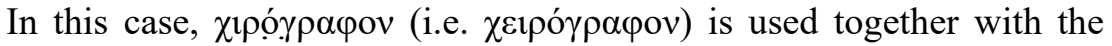

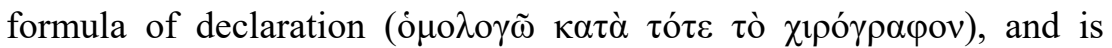
associated with some kind of declaration. Heron undertakes the

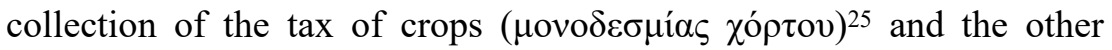
taxes, and $\chi \varphi \rho o ́ y \rho \alpha \varphi o v$ refers to the official document which records his

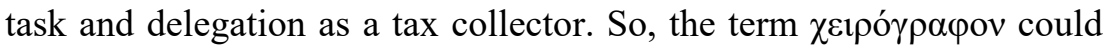
be utilised to express public and official declarations, not simply private contracts. ${ }^{26}$

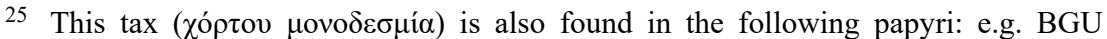
13.2283; P.Mich. 6.388; SB 1.5982; P.Wisc. 1.26. For the specific information, see P. J. Sijpesteijn, 'Receipts for $\chi o ́ \rho \tau o v ~ \mu o v o \delta \varepsilon \sigma \mu i ́ \alpha$ and Other Taxes', ZPE 87 (1991), 26367.

26 The following use of $\chi \varepsilon 1 \rho \gamma_{\gamma} \alpha \varphi \rho o v$ in P.Bodl. 1.31 (AD 169-176) is also related to

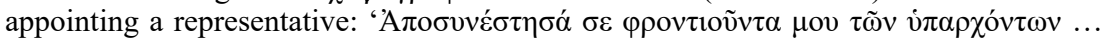

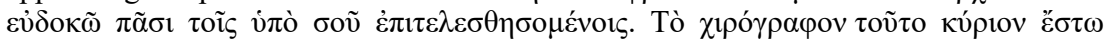

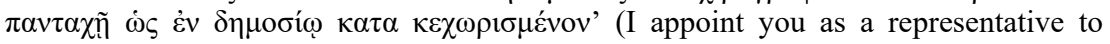
administer my property ... I delight in everything which will be completed by you. This hand-written declaration. May the Lord [i.e. the Roman emperor] be everywhere

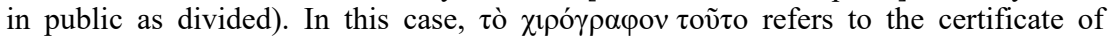
appointment, not a debt certificate. 
The following papyrus (P.Hib. 2:247) contains a priest's

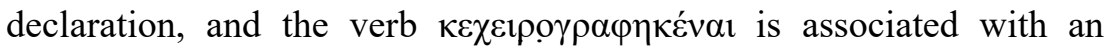

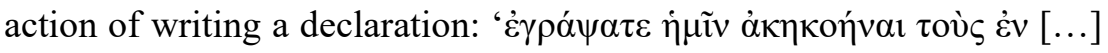

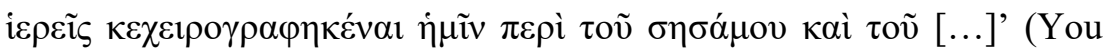
wrote us to obey what was written to us by the priests about the sesame

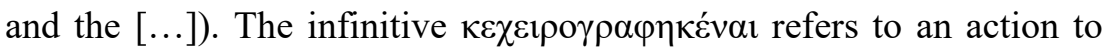
record the priests' declaration about the sesame. So, the handwriting

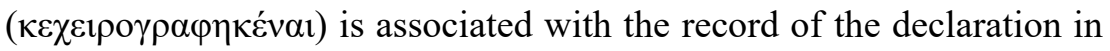
this case.

We also detect a formula used in the document containing orders or directions in the form of the sentence 'you or he/she received the order'. P.Oxy. 18:2185 (AD 92) includes a declaration for a grant of

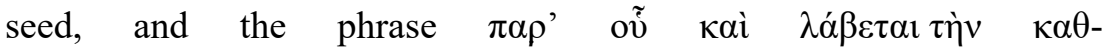

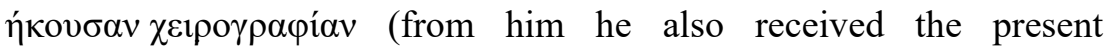
handwritten declaration) is employed after the declaration. ${ }^{27}$ In this

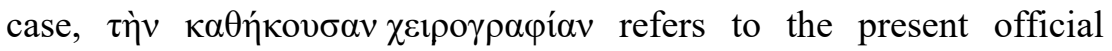
declaration. We observe a similar formula in ancient papyri.

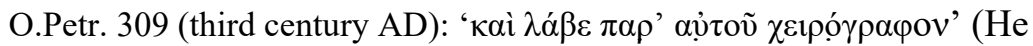
also received the present handwritten declaration from him).

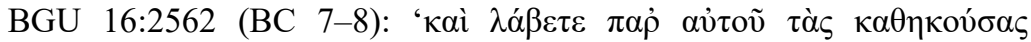

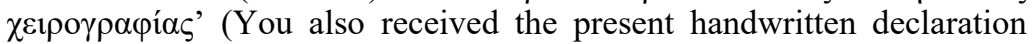
from him).

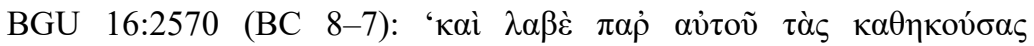

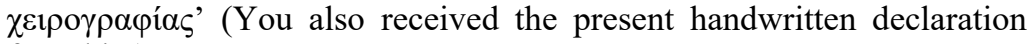
from him).

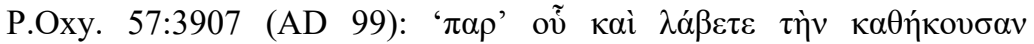

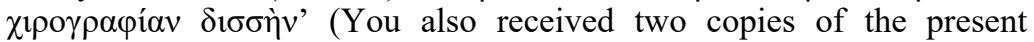
handwritten declaration from him).

So, the term $\chi \varepsilon i \rho o ́ \gamma \rho \alpha \varphi \circ$ or $\chi \varepsilon \iota \rho о \gamma \rho \alpha \varphi i ́ \alpha$ was not simply applied to a private document, but also to an official declaration. The term $\chi \varepsilon i \rho o ́ \gamma \rho \alpha \varphi$ ov could be used in the sense of the document which contains certain declarations, as shown above. Thus, we have sound fundamental that the term $\chi \varepsilon i \rho o ́ \gamma \rho \alpha \varphi \circ v$ and its cognate words were not merely used to refer to a private debt certificate, and could be employed for various purposes in respect of an official declaration.

Similarly, the term $\chi \varepsilon i \rho o \gamma \rho \alpha \varphi$ í $\alpha$ could be used to express the documents which record someone's oath. For example, we find the

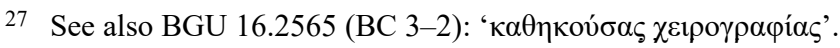


following mention in P.Ryl. 4:572 (second century BC):

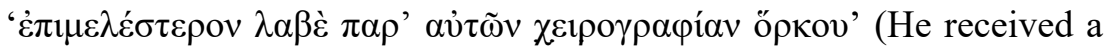
handwritten declaration of oath from them more carefully). 'This $\chi \varepsilon i \rho о \gamma \rho \alpha \varphi i \alpha$ is the handwritten document which recorded a royal oath

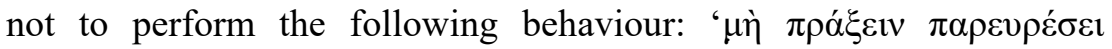

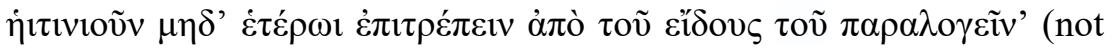
to practice according to the pretext permitted in the unreasonable form). So, the term $\chi \varepsilon i \rho о \gamma \rho \alpha \varphi$ í $\alpha$ refers to the statement of an oath in this case. We observe a similar case in P.Oxy. 2:260 (AD 59): ' $\Theta \dot{\varepsilon} \omega v$

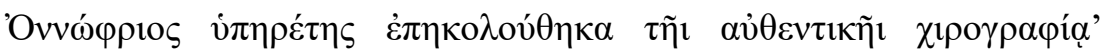
(Theon Onnophrios the servant. I have followed by the original declaration). In this case, the term $\chi \varepsilon i \rho o \gamma \rho \alpha \varphi i \alpha$ is also related to the promise of attendance in court. A similar usage of $\chi \varepsilon 1 \rho о \gamma \rho \alpha \varphi$ í $\alpha$ is found in P.Tebt. 3:801 (134BC): 'ő

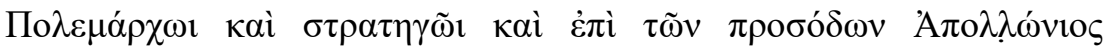

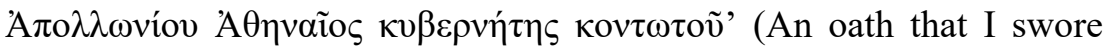

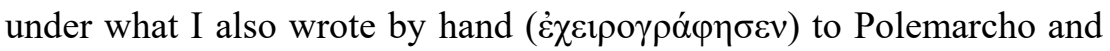
the leader concerning the income of Apolonios the son of Apolonios, Athenian, the governor crutched). ${ }^{28}$ So, $\chi \varepsilon i \rho o \gamma \rho \alpha \varphi i ́ \alpha$ was often used in the sense of a document on declaration of an oath or a promise.

In brief, we have explored many pieces of evidence that, contrary to Deißmann's definition and the present consensus, except for Arzt-

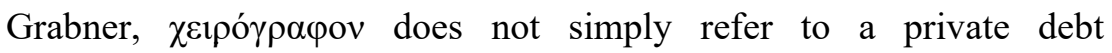
certificate, but was used to express various handwritten declarations and contracts including receipts, loans, contracts, and records of oath in ancient Greek papyri. The formula of declaration is often used with the

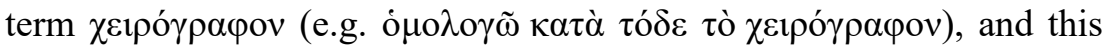
shows that $\chi \varepsilon i \rho o ́ \gamma \rho \alpha \varphi \mathrm{v}$ is associated with a document that contains

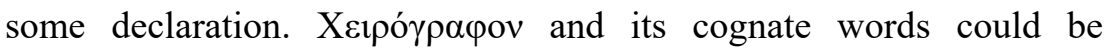

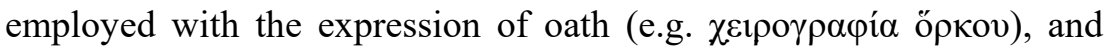
refers to the document which contains someone's oath or promise in that case. Thus, $\chi \varepsilon \iota \rho o ́ \gamma \rho \alpha \varphi o v$ can be defined as a handwritten contract or declaration used in both private and public situations. ${ }^{29}$

28 For this usage, see Chr.Wilck. 181 (BC 259-258); P.Tebt. 3.1.815 (BC 223-222); SB 5.8008 (BC 77); SB 5.8754 (BC 78), etc.

29 The compound verb $\dot{\pi} \pi \propto \chi \varepsilon \iota \rho \gamma \rho \alpha \varphi \varepsilon \tilde{v}$ (to sign by hand) could be used in similar

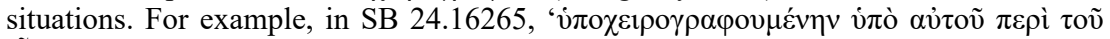

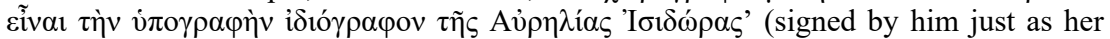
document signed by Aurelia Isidora). In this case, $\dot{\pi} \pi \circ \chi \varepsilon 1 \rho о \gamma \rho \alpha \varphi \varepsilon \tilde{v} v$ refers to signing on

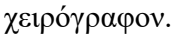




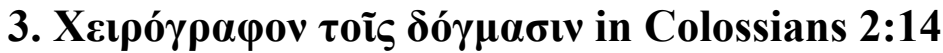

If $\chi \varepsilon i \rho o ́ \gamma \rho \alpha \varphi o v$ does not refer to a debt certificate, it is unlikely that Paul expected his readers to understand this term as the bond between God and humanity. Moreover, it should be noted that there is no expression concerining a debt in Colossians 2. Instead, it is more

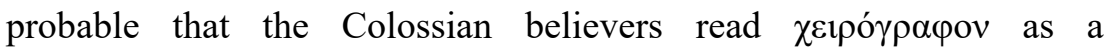
handwritten document relating to a declaration, promise, or oath. The modifier $\tau$ oĩ $\delta$ ó $\gamma \mu \alpha \sigma v$ can be considered as the dative case of

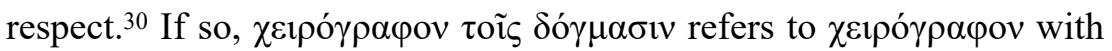
respect to the religious regulations.

Scholars diverge as to the meaning of $\delta$ ó $\gamma \mu \alpha$ in Colossians 2:14. Some interpreters understand the background of $\delta$ ó $\gamma \mu \alpha$ in Colossians 2:14 in terms of Hellenistic philosophy. ${ }^{31}$ Eduard Schweizer maintains that $\delta$ ó $\gamma \mu \alpha$ in Colossians 2:14 contains the religious features of the Pythagorean and Platonic idea. ${ }^{32}$ R. E. DeMaris contends that the false teaching is related to a sort of Middle Platonism. ${ }^{33}$ Yet, other scholars maintain that $\delta$ ó $\gamma \mu \alpha$ in Colossians 2:14 is associated with the Jewish ritual law. ${ }^{34}$

30 Walter, 'Die Handschrift in Satzungen Kol 2,14', 118. Cf. Stanley E. Porter, Idioms of the Greek New Testament (Sheffield: Sheffield Academic Press, 1992), 97-98.

31 Morna Hooker argues that there was no false or heretical teacher over whom Paul is fighting in Colossians and that he is not correcting a particular error of the Colossian church. See Morna Hooker, 'Were There False Teachers in Colossae?' in From Adam to Christ: Essays on Paul (Cambridge: Cambridge University Press, 1990), 121-36. Yet Hooker's argument has not been accepted by the majority of scholars. The majority view is that false teachers or errorists existed behind the Colossian church. First, pronouns $\tau ו \varsigma(2: 8,16)$ and $\mu \eta \delta \varepsilon i$ ( $(2: 18)$ were probably used with reference to a

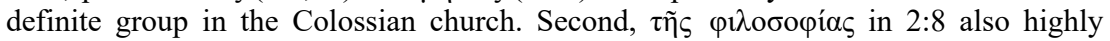
likely refers to a specific philosophy. Third, the present verb ' $\delta \sigma \gamma \mu \alpha \tau i \zeta \varepsilon \sigma \theta \varepsilon$ ' in $2: 20$ also implies that some specific error is being made in Colossian church at present. Fourth, in 2:8-23 (the so-called polemical core), the author of Colossians intensively delineates specific features of the teachings he objects to, which highly likely suggest that 2:8-23 reflects the actual errors of some Colossian believers. In addition, the following phrases seem to allude to slogans of the false teachings: 1) " $\pi \tilde{\alpha} v$ tò

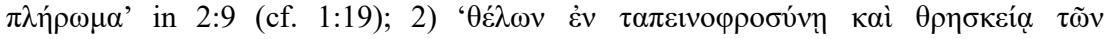

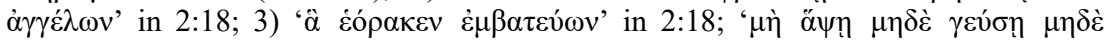

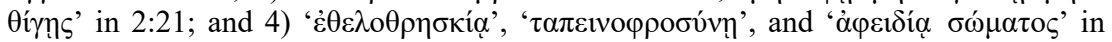
$2: 23$. The false teaching must be connected to regulations on food, drink, festivals, and calendric observance as in 2:16,20-21.

32 Schweizer, The Letter to the Colossians, 90.

33 Richard E. DeMaris, The Colossian Controversy: Wisdom in Dispute at Colossae (JSNTSS 96; Sheffield: Sheffield University Press, 1994), 58, 112.

34 Dunn, Colossians, 29-35; Wright, Colossians, 23-30; Allan Bevere, Sharing in the Inheritance, 53-59; Markus Bockmuehl, Revelation and Mystery in Ancient Judaism and Pauline Christianity (Tübingen: Mohr Siebeck, 1990), 179-80; Marianne 
Whether the false teaching contains Jewish features or not, it seems obvious that $\delta$ ó $\gamma \mu \alpha$ in Colossians 2:14 refers to the religious regulations required to the Colossian believers, and that it is related to ascetic regulations. It should be noted that a religious declaration or an oath to obey certain regulations was common in initiation rituals of ancient cults. For example, a papyrus which records a declaration or an oath in an initiation ritual of Mithras mysticism deserves attention: ${ }^{35}$

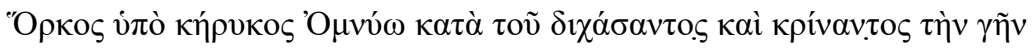

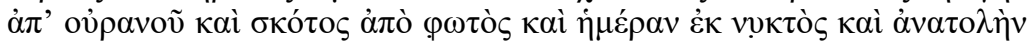

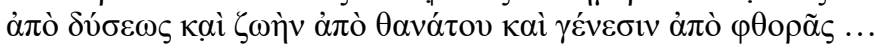

An oath under the messenger. I swear according to the one who distinguished the earth from heaven, darkness from light, day from night, and sun-rising from sunset, life from death, birth from destruction.

This oath was declared in the initiation ritual, and the one who swears requests a protection by Mithras according to the oath. We also detect oaths with regard to Mithras in ancient literature. For instance, Claudianus writes that a Persian king swore towards Mithras (De Consulatu Stilichonis 1:61-63). Xenophon also records an oath towards Mithras (Oeconomicus 4:24).

An oath in the initiation ritual was also significant in ancient Pythagoreanism. In Pseudo-Plutarch, Placita Philosophorum 1:3, we discover an oath sworn in the initiation ritual.

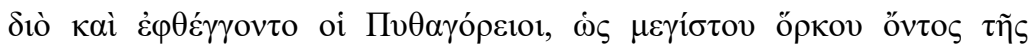

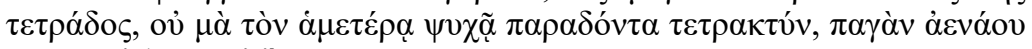

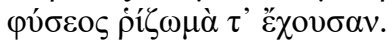

Therefore, Pythagoreans declared that there is the number four as the greatest oath, swearing towards the one who gave our mind tetractys ( $\varepsilon \varepsilon \rho \alpha \kappa \kappa \tau$ ś), source and root of eternal nature.

According to the citation above, we find that Pythagoreans take an oath with regard to tetractys (a Pythagorean triangular figure consisting of ten points) in their initiation ceremonies. In Pythagorean Golden Verses 2, we find Pythagoreans' emphasis on the significance of oath:

Thomson, Colossians and Philemon (Grand Rapids: Eerdmans, 2005), 6-9; Wilson, The Hope of Glory, 34-40; Bird, Colossians, 15-26; Andrew Bandstra, 'Did the Colossian Errorists Need a Mediator?' New Dimensions in New Testament Study, ed. R. N. Longenecker and M. C. Tenney (Grand Rapids: Zondervan, 1974), 329-43.

35 Vittorio Bartoletti, 'Frammenti di un rituale d'iniziazione ai misteri', Annali della R. Scuoli Normale Superiore de Pisa 6 (1937), 143-52. As for similar contents, see PSI 10.1162 . 
'First, admire the immortal gods in the order determined by the law (vó ${ }^{\circ} \varsigma$ ), and revere oath.' Isocrates also writes that the sacrifice is an external expression of piety, but keeping an oath is an expression of nobleness in Demonicus 13. ${ }^{36}$

The significance of declaration or oath in initiation rituals is also emphasised by some Jewish groups. In the Damascus Document, an oath is a precondition for entering the covenantal relationship with God, and this oath is related to the observance of the Jewish law (CD XV 5-8). In 1QH VII 17, the oath of the Qumran community is linked with entering the covenantal relationship and abiding by the Jewish law. The oath of the Qumran community is a part of the initiation ceremonies for the candidates and includes their declaration about obeying the Jewish law. Taking an oath occupies an important position in the initiation ceremony of the Essenes. Josephus writes that those who want to enter the Essene community have an obligation to take a solemn oath relating to the rules of the community (J.W. 2:142). Thus, we observe that the religious oath in respect of the community rules or the Jewish law was significant in some Jewish groups.

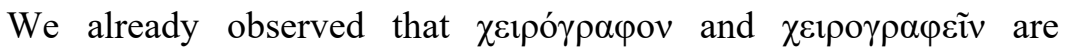
respectively employed to express the document and the action related to a declaration or an oath in the previous section. If so, $\chi \varepsilon \iota \rho o ́ \gamma \rho \alpha \varphi \circ v$ used in Colossians 2:14 can be related to the document which recorded the declaration to observe the religious regulations taught by the false teaching. Removing $\chi \varepsilon 1 \rho o ́ \gamma \rho \alpha \varphi$ v in Colossians 2:14, then, reflects the reason why the Colossian believers do not have to adhere to the regulations. Thus, Christ nullified the validity of their previous declaration on the regulations through his crucifixion in Colossians 2:14.

We can consider the verb $\dot{\varepsilon} \xi \alpha \lambda \varepsilon i \varphi \omega$ (Col. 2:14) in this context. The verb $\dot{\varepsilon} \xi \alpha \lambda \varepsilon i ́ \varphi \omega$ refers to an action of erasing a papyrus and is associated with the concept of freedom in the next papyrus (BGU 2:388):

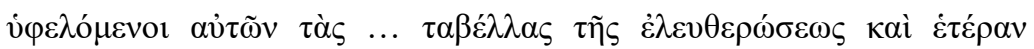

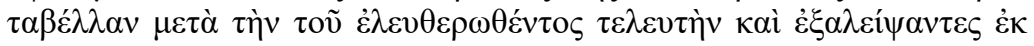

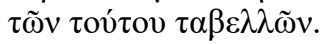

After the completion of manumission, the manumission document was

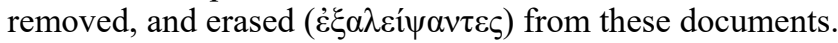

36 As Cicero states, 'whoever, therefore, violates his oath violates the faith' (Qui ius igitur iurandum violat is fidem violat). De Officiis 3.104 . 
The verb $\dot{\varepsilon} \xi \alpha \lambda \varepsilon i ́ \varphi \omega$ is used in the sense of erasing $\tau \alpha \beta \dot{\varepsilon} \lambda \lambda \alpha$ (a written note) and is related to manumission in this case. In BGU 2:388, manumission is not only freedom from slavery, but also accompanies erasing a written note on slavery. So, manumission means a freedom from the legal foundation of slavery in this case. We have already discussed that $\chi \varepsilon i \rho o ́ \gamma \rho \alpha \varphi \circ v$ in Colossians 2:14 can be linked with some Colossian believers' declaration or oath on religious regulations. Some Colossian believers were required to obey religious regulations, but the cross of Christ offers the foundation that the Colossian believers are free from these. Thus, Christ has set the Colossian believers from their previous declaration or oath to observe religious regulations through his crucifixion.

In summary, we do not find any proper reason we should read $\chi \varepsilon i \rho \cos _{\rho} \alpha \rho \mathrm{v}$ as certificate of debt in the synchronic context of Colossians 2. There is no explicit mention of indebtedness and of the condemnatory function of the Law in Colossians 2. Alternatively, it

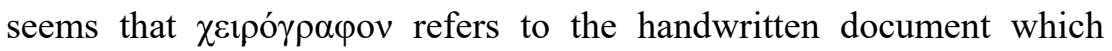
contains the declaration by the Colossians believers with regard to the observance of specific religious regulations.

\section{Conclusion}

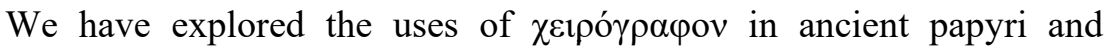
ostraca and have concluded that $\chi \varepsilon i \rho o ́ \gamma \rho \alpha \varphi o v$ does not refer to a debt certificate, contrary to Adolf Deißmann's view and the consensus ofsubsequent scholars (except for Arzt-Grabner). Xeıó redefined in the sense of the handwritten document which contains a private or public declaration or oath. We have also observed that

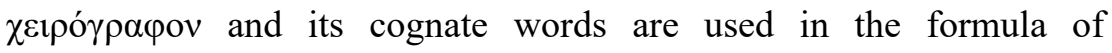

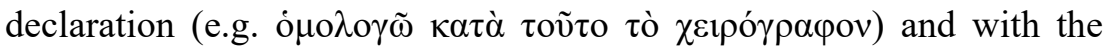

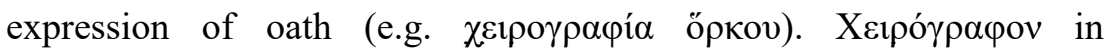
Colossians 2:14 can be interpreted in this context. Declaration or oath on the observance of the religious regulations was important in ancient

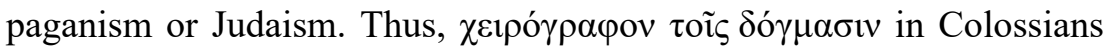
2:14 can be read as a handwritten document containing the declaration or oath regarding the observance of religious regulations. 